\title{
Refugee Camps: Emergent Presence to the Social Structure of the Palestinian Society
}

\author{
Jawad Dayyeh $^{1} \&$ Bassam Yousef Ibrahim Banat $^{2}$ \\ ${ }^{1}$ Social Sciences PhD. Program (Peace \& Conflict Research Line), University of Granada, Granada, Spain \\ ${ }^{2}$ Department of Applied Sociology, Al-Quds University, Jerusalem- Abu Dies, Palestine \\ Correspondence: Bassam Yousef Ibrahim Banat, Department of Applied Sociology, Faculty of Arts, Al-Quds \\ University, Main Campus, Jerusalem- Abu Dies, Palestine. Tel: 970-2252-2727. E-mail: bbanat@staff.alquds.edu \\ or bassambanat@yahoo.com
}

Received: April 11, 2019

doi:10.5539/ass.v15n5p95
Accepted: April 21, $2019 \quad$ Online Published: April 30, 2019

URL: https://doi.org/10.5539/ass.v15n5p95

\begin{abstract}
The study aimed to investigate the refugee camps issue as emergent presence to the social structure of the Palestinian society. The study approached the literature as a multi-dimensional phenomenon, which addressed both theoretical and applied research. The findings revealed that the Palestinian camps do not accurately reflect the structure of the Palestinian society, as they are emergent presence to the social structure of the Palestinian society. These camps depict the exposure of the Palestinian diaspora concentrations during the Nakba of 1948 and after the 1967 war. It reflects the social, economic, and cultural conditions of the period resulting from the uprooting of more than one million Palestinians from their cities, villages, and Bedouin sites of origin.
\end{abstract}

Keywords: refugee camps, social structure, diaspora, Nakba

\section{Introduction}

On 15 May 1948, the day that Britain declared an end to its mandate on Palestine, the Zionist movement declared the formation of Israel as a state on $78 \%$ of the Palestinian lands. They further uprooted Palestinians from twenty cities and four hundred and twenty villages. Suddenly, regardless of their wishes or future, about 957,000 Palestinians, or $66 \%$ of their residents, were rendered homeless, this was known as the Palestinian Nakba (setback) (Abu Sitta, 1997; Banat, 2002; Salama, 2006; Dayyeh et al., 2018).

This caused an almost complete dismemberment of the Palestinian society with all its components and physical bases which led to the emergence of a new phenomenon in the Palestinian society, the Palestinian refugee camps that rapidly spread throughout the West Bank and Gaza Strip, neighboring countries such as Jordan, Syria, and Lebanon and the rest of the world (Jarrar, 1995; Jibara, 1998).

These camps which bear witness to the catastrophe, the uprooting of Palestinians from their homeland, and their consequent homelessness, depict their daily sufferings on all levels: cultural, social, economic, and political. Since then, the people of Palestine still continue to wait for the political decision that can end their unspoken and seemingly endless suffering (Sayegh, 1983; Kana'na, 2000; Hussien, 2003; Allan, 2007; Banat et al., 2018).

According to the Palestinian Central Bureau of Statistics (PCBS) (2017), approximately half of the Palestinian population, estimated at around 7.5 million, live in all parts of the world and constitute the largest and oldest group of refugees in the world. They are distributed throughout the world as follows: (1) 1.5 million people as the original refugees from 1948; (2) 1.5 million as unregistered refugees; (3) 773,000 refugees displaced by the 1967 war; (4) 263,000 refugees living within the Palestinian Territory occupied in 1948.

Additionally, the percentage of refugees living in the West Bank, Gaza Strip and pre-1948 Palestinian territories is $41 \%$ of the total refugee population. The neighboring countries such as Jordan, Syria, Lebanon, Egypt and Iraq host about $43 \%$ of the total Palestinian refugees. Around $16 \%$ of Palestinian refugees are dispersed in the rest of the world (Banat, 2014).

"Israel" has completely disregarded the UN Resolution 194, which demanded that Palestinian refugees return to their homeland. All their attempts to return have failed; this led to the creation of a new stage, a Palestinian diaspora, which endeavors to grant Palestinians liberation to return after seventy years of the Nakba (UN, 1948; 
Abu Sitta, 2001; Banat, 2014).

\section{The Social Structure of the Palestinian Society}

A study of a society's social structure is essential to understand this society. In order to understand the Palestinian social structure, its local social organizations (substructures) which are represented by family, village, and Palestinian camps need to be studied and discussed.

\subsection{The Palestinian Social Structure During the Ottoman Regime (1917)}

Till 1917, the Palestinian social structure had begun to form a hierarchal feudalism, with basic alterations as dictated by the Ottoman reformation plan in the final years of the empire; these were called "Tanthimat". These proposals substituted the heads of the clans with notables and proprietors of the lands in Palestine. According to the British occupation of Palestine, its social structure was as follows: (1) The Ottoman ruler "Wali," his assistants from the army and Turkish employees. (2) Supervisors: They were a part of Palestinian economy and politics. They inherited their positions and responsibilities by birth. Moreover, they did not pay taxes, were exempted from military service, and had special financial privileges because they held elite religious positions. (3) Families of proprietors of the lands: They owned vast areas of wealthy Palestinian lands. They lived in cities and rented the lands out to the peasants working there. (4) Businessmen and traders in cities: They were the Palestinian bourgeois class who profited from the upcoming civilization, relative industrialization, and the advancement of transportation during the later stages of the Ottoman Empire. The majority of them were Christians, but there were a significant percentage of Muslims among them. (5) Handcrafters: They formed the traditional production class at the time of the Ottomans. They depended on the system of enclosed professional families who kept their trade secrets within the group. (6) Labor class: They were small in number and only began to form during the British Mandate era as a result of the growing commerce and production. (7) Peasants: They constituted $80 \%$ of the population, and suffered from poverty and persecution. Moreover, they had to pay several taxes although they owned very little land. There was a noticeable difference between the peasants and city dwellers at the economic, educational, and cultural levels (Smith, 1984).

During the British Mandate era on Palestine, the Palestinian social structure significantly transformed; this led the Palestinian society to turn into a labor class society. According to the Balfour Declaration in 1917, the British Mandate, and the Palestinian Peasants' Revolution of 1936, Britain subjected Palestine to social, political, and economic conditions that facilitated the establishment of a national homeland for Jewish immigrants in Palestine. These conditions were as follows: (1) Transfer of state-owned lands and the facilitation of sale and confiscation of lands aided in allocating them from Palestinian peasants to Jewish settlers. (2) Restrictions of Palestinian expansion in construction, education, industry, and agriculture, deprivation of political expression in administration and the right to self-determination of the Palestinian people for offering these facilities to the Jewish agency founded the Jewish settlers' society, and thus denied the Palestinians' nationality. (3) Intentional and exponential increase in the number of Jewish immigrants using every possible method, legitimate and illegitimate, led to the forceful expulsion of Palestinian residents and peasants to cities. (4) Expulsion of Palestinians by Britain with the help of the Jewish settlers led to the declaration of the land as the state of the Jews. Then, Britain withdrew from Palestine, consequently subjecting the residents to the cruelty of Zionist gangs who strategically evacuated them during mid-1948. (5) Transfer of the fate of the Palestinian question into non-Palestinian power that occurred as a result of the Arab countries and the United Nations meddling into it. This influenced the Palestinian political leadership which caused it to fail in achieving any of the aims of the Palestinian people. This was one of the factors that contributed to the fall of the 1936 Revolution. (6) Britain's association with the establishment of a Palestinian bourgeois class and Arab regimes created conflict within themselves because of the absence of peasants' leadership. This conflict gradually escalated, leading to the 1948 war, in which the Arabs were defeated and the State of Israel was declared. This caused further expulsion of Palestinians (Smith, 1984; Al-Quds Open University, 2000: 110).

\subsection{The Palestinian Social Structure Post 1948}

After the eviction of Palestinians from their homeland, they began to be influenced by other social structures in other Arab and non-Arab societies, such as the Egyptian, Syrian, Lebanese, Jordanian, and Arab gulf communities. Moreover, the influence of different cultures, such as the European and American cultures, was already increasing. Israel's influence on the Palestinian social structure was through its negation and destruction. However, their immigration patterns that this destruction caused helped the Palestinians to acquire new skills and roles, update their traditional roles, and learn about the new Arab local and international cultures that further enhanced their experiences. As a result, the scale of ranks and roles changed. New classes and groups, such as intellectuals and capitalists, emerged, while the status of land proprietor families lowered. Additionally, the 
Nakba experience caused the materialization of the collective Palestinian consciousness which improved the relations among groups of people, leading to the rise of a new youth leadership.

Further, the Palestinians in the West Bank and the Gaza Strip were concentrated within a certain social structure that was still connected to Palestinian lands. Despite living under occupation, these settlements have preserved their Palestinian lifestyles. They have developed an internal resistance movement that has influenced the course of the Israeli Palestinian struggle, even as they suffer from the consequences of the Israeli occupiers' despotic and capricious measures such as the following: (1) Suppression methods such as imprisonment, expulsion, arrest, assassinations, and collective punishment. (2) Expulsion and displacement of families and rejection of political rights and Palestinian national identity. (3) Frequent construction of new settlements on Palestinian lands. (4) Exploitation of the Palestinian labor force by paying them the lowest wages in the Israeli labor markets. (5) Withholding education and undermining economic institutions by increasing the economic dependence of the settlements and their consequent reliance on the Israeli economy (Hirst, 1977; Abu Arafa, 1981; Thorpe, 1984).

\section{Palestinian Family}

The Palestinian family is crucial in generally preserving the social, cultural, political, and economic identity of Palestinian society, especially considering the difficult conditions and the cataclysmic events that they have experienced over the past 60 years at least. These have directly and lastingly affected the Palestinian family and its members.

Certain essential characteristics that distinguish the Palestinian family is derived from its environment in principle, and their difficult experiences of external coercion: (1) About 78\% of Palestinian people till1948 were living in rural areas; their source of livelihood was cultivating land and raising cattle. (2) Their attentiveness to land indicates the high frequency of face-to-face social relationships among individuals; fatherhood and kinship based on blood bonds are important to them. They manage these relationships through cooperative social processes to mainly preserve the family and its center along with executing its multiple duties for the individual and society. Moreover, the social activities, responsibilities, and centers of the Palestinian family are derived from the land; thus, the Palestinian culture and its different patterns are linked to it. The size, value, and standards of the Palestinian family, concerning extended family, nuclear family and average-sized family, depend on the land it owns or works on. (3) The Palestinian family has rapidly transformed its structure and size as a result of the coercive factors which had been accumulating following the First World War and proliferated in 1948 as the collective, forced expulsion of the Palestinian family at the hands of the Zionist gangs. About two million Palestinians from the Palestinian cities, villages, and nomads were displaced and the social structure of the Palestinian concentrations was completely destroyed. Further, they dispersed in the Arab and international diaspora. The Palestinian family was exposed to yet another shock in 1967 when more than 300,000 Palestinians were dispersed in the diaspora, and half of the lands of the West Bank and Gaza Strip were confiscated by the Israelis (Sayegh, 1983; Thorpe, 1984; Kana'na, 2000).

The Palestinian family comprises six standards that define it: extended family, patriarchy in kinship, patriarchy in distance, patriarchy in residence, polygamy, and dependence on a very closed marriage. The extended Palestinian family is supported by three or four generations, where its members live as one economic unit and share income and life expenses. Additionally, the father of the family is the authoritative figure; it is patriarchal in kinship because its lineage always refers to the father and patriarchy among relatives as the official relationship is determined through the father. It is patriarchal in residence as when a woman gets married, she moves from her father's house to her husband's house; additionally, the family depends on a very closed marriage, and it allows polygamy under certain conditions and Sharia (Muhawi \& Kana'na, 2001: 20).

The knowledge regarding the distribution of authority in the Palestinian society helps in realizing the social position of the woman in the family. Authority is given to the individual based on three criteria: gender, age, and rank within the family. These three criteria apply to the father or grandfather of the family; his authority is almost unquestionable on every member of the family, while these criteria do not apply to the woman. According to her rank, the wife of the principal father exercises her authority on other women in the family (Muhawi \& Kana'na, 2001: 26).

The father-son relationship is the defining relationship of the entire familial system; it is based on a strong bond that the society depicts through absolute obedience of the father. According to this created image, an ideal son rarely opposes his father's word regarding the family. The society reveres a son who announces his allegiance and obedience in all his actions and decisions to his father. On the other hand, the father-daughter relationship is very significant in the hierarchy of the family since the father is the only one who holds the right of consent to his daughter's marriage. Therefore, he can lay the foundation for another relationship. The girl is always 
affiliated and belongs to her father's family. Subsequently, the wife only carries her husband's family name after marriage. Thus, the father and brothers are responsible for their girl as long as she lives, irrespective of her marrying and moving to her husband's house or staying at her father's house (Muhawi \& Kana'na, 2001: 28).

On the other hand, the relationship between the mother and her sons is based on gentleness and love, as in the case of brothers and sisters; it is generally close and kind. Family solidarity is often considered one of the main features of a Palestinian family, and the child is raised with this value at different levels including responsibility for the children's care and guidance. The father, mother, brothers and sisters, some aunts, uncles, and cousins follow this. Most of the economic and social activities and the important decisions that influence the lifestyle of a Palestinian family are administered by the father. Furthermore, the role of the mother is complementary; it involves tasks such as giving advice to her husband whenever he needs it.

\subsection{Socialization in the Palestinian Family}

Socialization in the Palestinian society revolves around religious education and the teachings of Islam. Islam is the major religion among Palestinian people; therefore, its teachings influence the daily social and cultural life of their children. Consequently, it also influences their struggles, thus instilling in the youth the values of heroic sacrifice since their early childhood. This is further reinforced by the struggles of their daily occupation and the crimes committed against them. As in any Arab society, patriarchal relations characterize the Palestinian family's process of socialization. Discrimination between the two genders starts at a very early age in an individual's life: boys are raised in the men's world, while the girls are raised in the women's world. This distinction spreads across educational, moral, aesthetic, intellectual, philosophical, and even practical contexts. It is evident that guidance for the males is inclined to the confirmation of manhood, bravery, chivalry, courage, eloquence, and stamina, while for the females, it is oriented towards feminity, decency, chastity, child rearing qualities, home economics, and stability (Muhawi \& Kana'na, 2001; Lachkar, 2002; Banat et al., 2018).

Palestinian socialization also involves highlighting their duties more than their rights. The Palestinian family and educational systems focus on making their members ready to make sacrifices and offer more services than secure rights and gains. On further analysis of original Palestinian behavior which influences this type of education, the extent of the Palestinians' interest in their societal duties and keenness on preserving social reputation and the bonds shared by them becomes evident.

To sum up, the Palestinian society was under aggression in an attempt to destroy its economic, cultural, political and social systems through violence, withdrawal of basic necessities, and immigration. This is reflected directly on the Palestinian family system as its structure, relationships among its members, size, concentrations, and other psychological and cultural influences burdened its economic, social, and political functions; it is held responsible for providing the referential framework as a preserver of values and executor of criteria of the behavior and belongingness of its members. This caused the development of a special relationship between the members of the family, within the ethical framework that persisted in spite of the difficulties caused due to the social and geographical distances among the members of the family. This relationship is developed in the individual's behavioral patterns with reference to other family members: care of the old and young, education and learning, financial support, regardless of the distance separating the members and the persistence to stay connected through all available means despite hurdles such as distance, homelessness, and displacement (Sayegh, 1983).

\section{Units of Palestinian Social Structure}

\subsection{Palestinian Villages}

As the Palestinian family is the basic unit of the social system, the Palestinian village is the first unit of its social structure as it extends the relationships beyond the family, leading to the emergence of its culture, economics, and politics. The Palestinian village is a population cluster, influenced by the physical, geographic, and social environment of its place of origin; however, it almost became an independent administrative, political, social, cultural, and economic unit that was semi-detached from the Palestinian Bedouin settlements and the cities. It caters for its own production and consumption. The villagers depend mainly on landed property through agriculture and raising cattle for their livelihood. A group of individuals and families who belong to the same father reside in a village. This clan or curia consists of several families linked by the same father, especially through special relationships based on blood and kinship (Arraf, 1985).

In 1948, entire villages were annihilated, and they suffered loss of identity as a population cluster. They died out as a social and cultural system built by a specific time and place. In fact, "Israel" has completely demolished hundreds of Palestinian villages and cities. This prevented any opportunity of developing what was left. However, the cooperation among the clans and families of the village defied the suppression and persecution; their 
experiences unified the village structure. Gradually, this defined the social bonds of conforming to family and an almost absolute fidelity to their village. This led to the peasants' resistance during the Palestinian Revolution in 1936. Thus, the village participated in the Revolution of 1965 and all subsequent ones (Banat, 2010).

\subsection{Palestinian Bedouins}

The Palestinian Bedouins have suffered throughout the same distinctive Palestinian experience since the end of the Ottoman regime following the First World War, during the British Mandate era till 1948 and after 1967. Based on the size of the population clusters, the Palestinian Bedouins rank after the rural families who live in villages in the same place during the same time; the Palestinian Bedouins principally depend on raising cattle for their livelihood and constantly travel (Budairi et al., 1990).

\subsection{Palestinian Refugee Camps}

The Palestinian refugee camps do not accurately reflect the structure of the Palestinian society, as they are emergent presence to the social structure in the Palestinian society. These camps depict the exposure of the Palestinian diaspora concentrations during the Nakba of 1948 and after the 1967 war. It reflects the social, economic, and cultural conditions of the period resulting from the uprooting of more than one million Palestinians from their cities, villages, and Bedouin sites of origin. As a result of this crime, the term diaspora was introduced to the dictionary of Palestinian life and developed into its present condition (Banat et al., 2018).

A Palestinian refugee is anyone who has been expelled from their natural place of residence during or after 1948 or departed from it for any reason but was not permitted to return to Palestine by Israelis. One-third of the Palestinian refugee population lives in 58 official camps established between 1948-1950 in Jordan, Syria, Lebanon, the West Bank and Gaza Strip. The remaining two-thirds live in the cities and towns of the host countries, and in the cities of the West Bank and the Gaza Strip. There are 10 camps in Jordan, 9 camps in Syria and 27 camps in the Palestinian Territories: 19 camps in the West Bank and 8 in the Gaza Strip (Banat, 2002: 46; Sobani, 2007; Banat et al., 2018). The rest constitute a part of the Arab diaspora in Arab countries outside the camps and in the international diaspora, i.e., scattered beyond the limits of the Arab countries across the two Americas, Australia, and other countries.

Palestinian Refugees constitute $47.9 \%$ of the total population in the West Bank and Gaza Strip, accounting for a total of 2,159,015 refugees (PCBS, 2017).

In 1949, the United Nations Relief and Works Agency for Palestine Refugees (UNRWA) founded Palestinian camps. Since their establishment, the camps are monitored and supervised by the UNRWA. It seeks to fulfill the residents' basic needs for health or education and in kind as feasible. The majority of the camp residents live in small-sized houses that do not exceed 50 square meters with two to three rooms per family. These houses officially belong to the UNRWA. These camps are densely populated because of the ever-increasing number of newborns (Banat, 2002, 2010).

The majority of the camp residents work outside their camps as their basic source of income as they had to abandon their primary source of income in 1948 when they were displaced. Additionally, the administration of the camp is under the supervision of the UNRWA, which appoints a director, carrying a refugee card, for the camp. This director is responsible for efficient functioning of the affairs of the camp, including the distribution of allowances, aid, registration of newborns, and the supervision of the different facilities in the camp such as schools, clinics, and recreation centers (Budairi et al., 1990).

As for the infrastructure of the camps, there are water and electricity networks. Additionally, the sewerage networks have recently been extended to different parts of the camp. Moreover, although a telephone network is set up inside each camp, it does not cover all its areas. Many centers and facilities offer services to meet the essential needs of the residents. There are two schools in the camp, one for boys and the other for girls. Both of these schools teach grades until the preparatory stage. Along with being in the camp, mosques have been erected in kindergartens and a UNRWA clinic too. Warm and close social relationships can be witnessed throughout the camp among the camp residents and the Palestinian community. These relationships are based on love, cooperation, and fidelity towards the community. This sentiment has been strengthened due to the various shared experiences of the persecution since 1948 as a large number of intellectuals in the camps hold different academic degrees in different specializations. This notable new leadership prioritizes the interests of the camp in particular and the homeland in general. Since the Palestinian Nakba, the sons of the camps continue to lead the national struggle by following the footsteps of their forefathers their homeland's liberation and their return to their original homeland. The culmination of this national struggle of the camp residents often manifested in the number of martyrs and suicide martyrs (Istishhadiyin) in all the national and Islamic factions and organizations 
(Budairi et al., 1990; Banat, 2002).

\section{Conclusion}

The diaspora experience has indelibly impacted the Palestinian social structure as follows: (1) There was a loss of land and sources of income, cold weather, and scarcity of food. The search for relatives, grief over martyrs, life in camps or in the open, and charity from others and their pitying looks further worsened the conditions. All these, among other accompanying experiences wounded the Palestinians in a way that they would never heal. These permanent scars will be carried across generations until the day they return to their homeland. (2) The specific composition of the peasants and the Bedouin (nomad) and, generally, of the city according to its environmental and cultural formation originates from the land. Thus, displacement and uprooting have become fatal because of the indescribable loss and burial. If it were not for the family bonds, Islamic religious values of patience and supplication to God, the Palestinians would not have withstood the dissolution of the self and deterioration of their structures, humiliation, and cruelty that they have been exposed to (Sayegh, 1983). (3) Palestinians have been focusing on education and strengthening their family bonds. They have also started regaining their peasant experience; accordingly, they have planned the camp, in terms of physical construction or social structure, based on the architecture of the villages that they left. However, many changes have occurred, such as the class structure, the ranks and responsibilities, and the social status due to social isolation, family disintegration, and Israeli political persecution. All these factors have significantly influenced the outbreak of resistance, self-defense, sacrifice, glorification of martyrdom, and the struggle to regain land, honor, and dignity.

The impact of the 1948 Nakba on Palestinian society and its various dimensions and consequences, including the suffering of the Palestinian refugees, are still manifest in our every day. There are about 7 million Palestinian refugees at home and in the diaspora. Their number has steadily increased since 1948, and till this date they continue to endure extreme conditions in the camps.

In spite of the evacuation and rapid change in the structure of the Palestinian society, it has maintained its social unity in terms of its economic, cultural, social, and political systems. Along with being forced to leave their village, the spiritual eagerness and homesickness that fill their souls and the hearts still influence the behavior of every Palestinian member and their families. This has helped the resistance to rise in all its military, political, social, and intellectual forms.

\section{References}

Abu Arafa, A. (1981). Settlement: The practical application of Zionism. Jerusalem: Abu Arafa Agency for Press and Publication (Arabic version).

Abu Sitta, S. (1997). History of the Nakba. London: Palestinian Return Centre (Arabic version).

Abu Sitta, S. (2001). The right of return is sacred, legal and possible. Beirut: Arab Institute for Research \& Publication (Arabic version).

Allan, R. (2007). From the village to the camp: The role of Palestinian rural refugee women in preserving the family 1948-1962. Ramallah: Society of In'ash El-Usra, Center Studies of Palestinian Society and Heritage (Arabic version).

Al-Quds Open University (2000). Palestinian community. Jerusalem: Modern Arab.

Arraf, S. (1985). The Palestinian Arab village. Jerusalem: Arab Studies Society (Arabic version).

Banat, B. (2002). Arroub camp following fifty-four years of the Nakba 1948-2002. Jerusalem, International Christian Society (Arabic version).

Banat, B. (2010). Palestinian suicide martyrs (Istishhadiyin): facts and figures (Doctoral Dissertation). Granada, The University of Granada. Retrieved from https://hera.ugr.es/tesisugr/18599424.pdf

Banat, B. (2014). Palestinian refugees: Facts and figures. Conference: The National Statistical Week. Jerusalem: Al-Quds University, main campus, Abu Dies, April 27-28.

Banat, B., Entrena-Durán, F., \& Dayyeh, J. (2018). Palestinian refugee youth: reproduction of collective memory of the Nakba. Asian Social Science, 14(12), 147-155. https://doi.org/10.5539/ass.v14n12p147

Budairi, M., Tamari, S., Sabella, B., \& Zagha, A. (1990). Palestinian society in the West Bank and Gaza Strip. Akaa: Dar Al-Aswar (Arabic version).

Dayyeh, J., Banat, B., \& Barmil, H. (2018). Traumatic experiences of the Nakba: a case study of the first generation. European Journal of Social Sciences, 57(3), 303-313. Retrieved from https://www.europeanjournalofsocialsciences.com/issues/PDF/EJSS_57_3_05.pdf 
Hirst, D. (1977). The gun and the olive branch. London: Faber and Faber.

Hussien, G. (2003). Israeli terrorism and legitimacy of resistance and martyrdom operations. Damascus: Zorai Press (Arabic version).

Jarrar, N. (1995). Palestinian forced migration (S. Mahmoud, Trans.). Ramallah, Academic Program for Forced Migration (Arabic version).

Jibara, T. (1998). History of Palestine. Amman: Dar Alshorok (Arabic version).

Kana'na, S. (2000). Palestinian diaspora: Migration or displacement? (2nd ed.). Ramallah: The Palestinian Diaspora and Refugee Centre (Shaml).

Lachkar, J. (2002). The psychological make-up of a suicide bomber. Journal of Psychohistory, 29(4), 349-367. Retrieved from https://www.suicideinfo.ca/resource/siecno-20030360/

Muhawi, I., \& Kana'na, S. (2001). Speak bird, speak again: Palestinian Arab folktales. Beirut: Institute for Palestine Studies (Arabic version).

Palestinian Central Bureau of Statistics (2017). Palestinians in the diaspora. Ramallah: Printing Press (Arabic version).

Salama, S. (2006). Palestinian refugees, the importance of the United Nations Relief and Works Agency for Palestine Refugees (UNRWA) and the Office of the United Nations High Commissioner for Refugees (UNHCR). Ramallah: Department of Refugee Affairs (Arabic version).

Sayegh, R. (1983). The uprooting of the Palestinian farmers to the revolution (Khaled Ayed, Trans., 2nd ed.). Beirut: Arab Institute for Research (Arabic version).

Smith, P. (1984). Palestine and the Palestinians. Beckemhan: Groom Helm Ltd.

Sobani, S. (2007). The development of Palestinian population in the Diaspora and historic Palestine. Ramallah: Ramallah Center for Human Right Studies (Arabic version).

Thorpe, M. (1984). Prescription for conflict. Washington D.C.: Foundation for Middle East.

United Nations (1948). United Nations General Assembly Resolution 194 (III). Geneva.

\section{Copyrights}

Copyright for this article is retained by the author(s), with first publication rights granted to the journal.

This is an open-access article distributed under the terms and conditions of the Creative Commons Attribution license (http://creativecommons.org/licenses/by/4.0/). 